\title{
TM-Landsat imagery applied to the study of the impact of global climate change on a tropical coastal environment during the last deglaciation
}

\author{
M. L. VIANNA, A. P. CABRAL and D. F. M. GHERARDI† \\ Instituto Nacional de Pesquisas Espaciais-Divisão de Ciências da Terra, \\ C.P. 515, São José dos Campos, SP, 12201-970, Brazil
}

(Received 1 October 1991; in final form 14 June 1993)

\begin{abstract}
The discovery and subsequent mapping of an ancient shoreline at $25 \mathrm{~m}$ depth in N-E Brazil by TM-Landsat imagery is described. The study area is located on a tectonically stable part of the Brazilian shelf which presently shows a minor uplift rate of $0.2 \mathrm{~mm}$ year $^{-1}$, to the north of Natal in the State of Rio Grande do Norte. This submerged shoreline is characterized by the occurrence of a large number of long beachrock outcrops ( $>3 \mathrm{~km}$ in length), observed by diving, which are comparable to their analogues seen on the present-day beaches of the adjacent coast. The good state of preservation of this shoreline and the large number of carbonate rock 'reefs' on it suggest abruptness of a return to transgressive sea-level trend with high growth rates subsequent to a long-lived sea-level relating to the $11000-9000 \mathrm{yr}$ B.P. band. By reviewing high resolution paleoclimatic data from this period, we conjecture that this stillstand could be a consequence of the Younger Dryas cold event in the north Atlantic, which might have also had importance as a driving morphogenetic process for coasts in a global scale.
\end{abstract}

\section{Introduction}

The issue of sea-level rise caused by global climatic change is presently considered of great importance, especially in connection with the possible consequences of the increasing input of greenhouse gases into the atmosphere. However, although abrupt climate changes at the end of the last glacial cycle at around 10000 B.P. have been extensively studied, the related issue of abrupt sea-level rise and its global and regional consequences have not received the same attention.

Geomorphological data and radiometric dating obtained on coastal marine carbonate platforms in the last three decades provided, in fact, great impetus into the study of Pleistocene climatic changes (Imbrie and Imbrie 1979).

For the case of the last deglaciation, a considerable number of papers and discussions have been centred on the subject of sea-level change (Van de Plassche 1986, Tooley and Shennan 1987), with the main concepts evolving from so-called global eustatic curve determination based on ancient strandlines (Fairbridge 1961) to the careful determinations of local, relative sea-level curves and relative regional patterns that can be collectively integrated into a global four-dimensional record.

†Present address: Royal Holloway University of London, Geology Department, Egham Hill, Egham, Surrey TW20 0EX, U.K. 
However, integration of findings of ancient submerged beaches preserved on continental shelves and islands into the picture of sea-level rise as seen from the point of view of paleoclimatologists (e.g., Fairbanks 1989) is still lacking.

The present work gives an example of how one can get interesting insights by attempting such an integration, even prior to precise local dating studies. It also intends to show the usefulness of TM-Landsat imagery of large submerged areas up to $30 \mathrm{~m}$ plus depth to suggest a line of geomorphological work related to abrupt climate change. Instead of attempting a complete paleogeographic reconstruction of the study area, this work suggests the utility of tracing old shorelines continuously, if possible through different tectonic provinces, correcting their present-day depths by use of estimates of uplift or subsidence rates that can presently be obtained by differential SAR image interferometry (Gabriel et al. 1989), or from classical tidegauge-based sea-level records. With this kind of normalization, we believe it is safe to correlate ancient Holocene shorelines found in different parts of the world. The ultimate integration of such data with abrupt climate change episodes which caused variable meltwater pulses into the ocean, can help in the location of time zones where precision of the dating methods should approach sub-century time scales. These preserved shorelines seem to indicate the abruptness of the onset of high growth rates of sea-level subsequent to long stillstands.

Our use of orbital data follow the same philosophy as the one pointed out by Van Andel and Lianos (1984), who showed feasibility of using inexpensive seismic reflection equipment in the search for strandlines. In fact, for regions where the water is very transparent at visible spectrum wavelengths, the number of reports in the literature on the appliction of remote sensing to bottom composition determination, bathymetric and submerged feature mapping, has increased during the last 15 years (Polcyn and Lyzenga 1975, Lyzenga 1978 and 1979, Spitzer and Dirks 1987, Jupp 1988, Hick and Scoones 1990, Van Hengel and Spitzer 1991, Vianna et al. 1991).

Integration of our field data with a global picture of climate and sea-level evolution during the Younger Dryas chronozone is attempted in the Discussions section, where some new interpretations of findings by other authors are also suggested.

\section{Study area}

The study area represents the northeastern portion of the Continental Shelf of the State of Rio Grande do Norte (Brazil), east of Cabo Calcanhar (4'55' S to $5^{\circ} 10^{\prime} \mathrm{S}$ and $035^{\circ} 10^{\prime} \mathrm{W}$ to $036^{\circ} 10^{\prime} \mathrm{W}$ ) (figure 1). A unidirectional, topographically rectified current in the SE-NW direction is predominant with higher velocities values appearing in the period of June-October (Vianna et al. 1991). The shelf breaks near the $50 \mathrm{~m}$ isobath, limiting this shallow shelf (figure 1 ).

River discharge in this area is presently negligible, leading to a low suspended sediment concentration. This aspect, associated with a low phytoplankton productivity, causes the higher water transparencies observed.

These conditions allow the acquisition of remote sensing data of the seafloor up to $40 \mathrm{~m}$ isobath (Vianna and Cabral 1992). Concerning sediment facies mapping and shallow seismic profiling, there is a modest data base. However, a rough description can be obtained from França et al. (1976) and Vianna et al. (1991). 


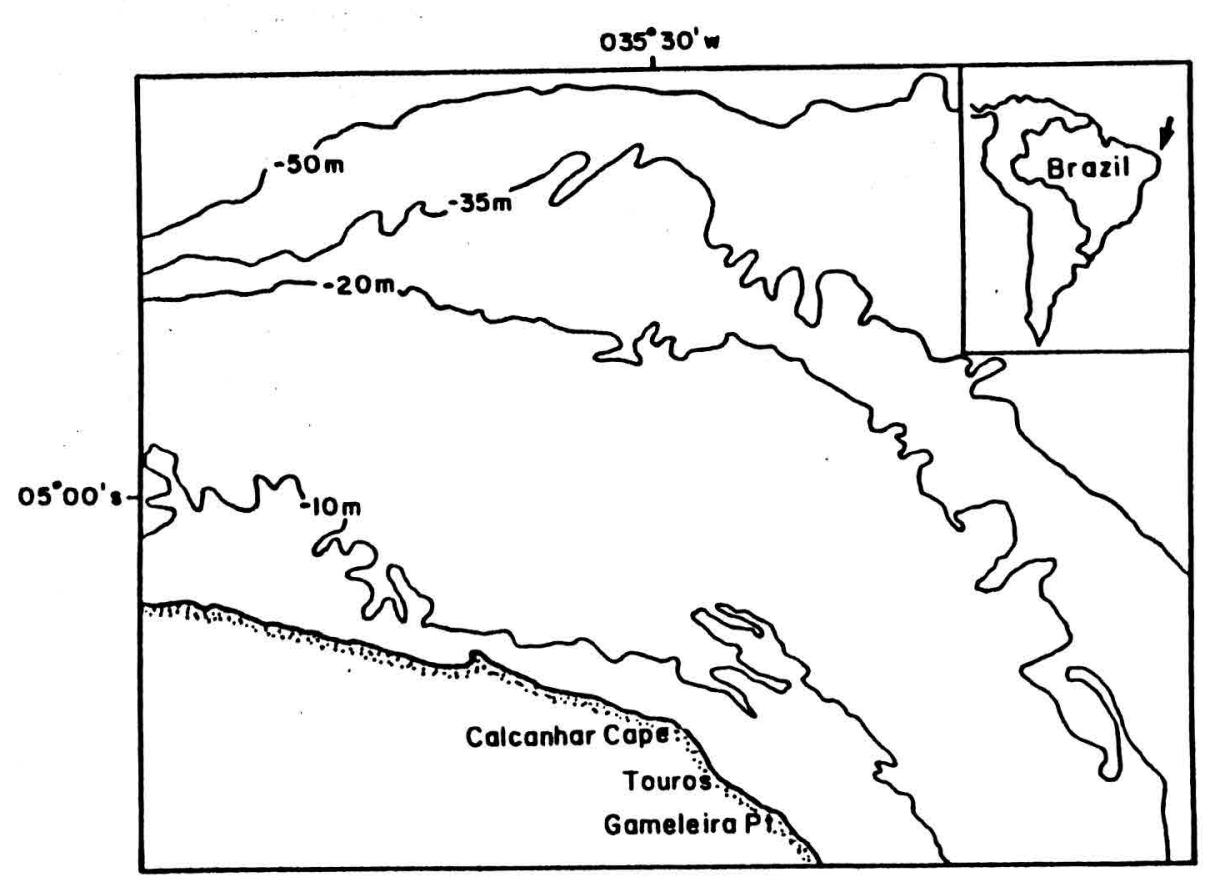

Figure 1. Geographical location of the study area.

\section{Methods}

A TM-Landsat image, path/row 214/64, quadrant A, bands 1 and 4, passage 5 January 1989, was used (figure 2). TM Band 4 was chosen to delineate the present coastline and TM Band 1 to explore the maximum transmittance zone of the visible spectral range on water, centred at $475 \mathrm{~nm}$.

The image recorded on CCTs was geometrically corrected by the Divisao de Geraçao de Imagens (DGI-INPE) by using a cubic convolution algorithm.

Image processing techniques were applied using the Sistema de Tratamento de Imagens (SITIM), developed by INPE, and the PC-SEAPAK System, developed by Goddard Space Flight Center/General Sciences Corporation. To minimize striping effects a median recursive filter with a 7 by 3 points moving window was used, following the methodology used in Cabral et al. (1990). The contrast enhancement using histogram modification techniques helped the feature discrimination in the images.

Existing bathymetric data, retrieved from Brazilian Navy smooth sheet B800-3/71, were inserted in the GIS system (SGI-INPE). The digitization and data processing are based on methodology described in Solewicz et al. (1989). Isobath charts and a 3-D model were produced as an aid for a better visualisation of the larger scale bottom topography.

The bathymetric chart producted in the GIS system was registered with the 1989 TM image to compare the published bathymetric data with the ones obtained by the field work and imagery (figure 3). This registration was implemented using five control points, which leads to an error of around $60 \mathrm{~m}$.

The lack of perfect coincidence between the morphologies suggested by the lowresolution bathymetric data and the image in the sub-kilometre scale motivated the use of echosounder transects to characterize the submerged beach profile.

The methods used in the field work have been described in Vianna et al. (1991). Samples of the long linear outcrops were obtained by use of sledge-hammers. Thin 


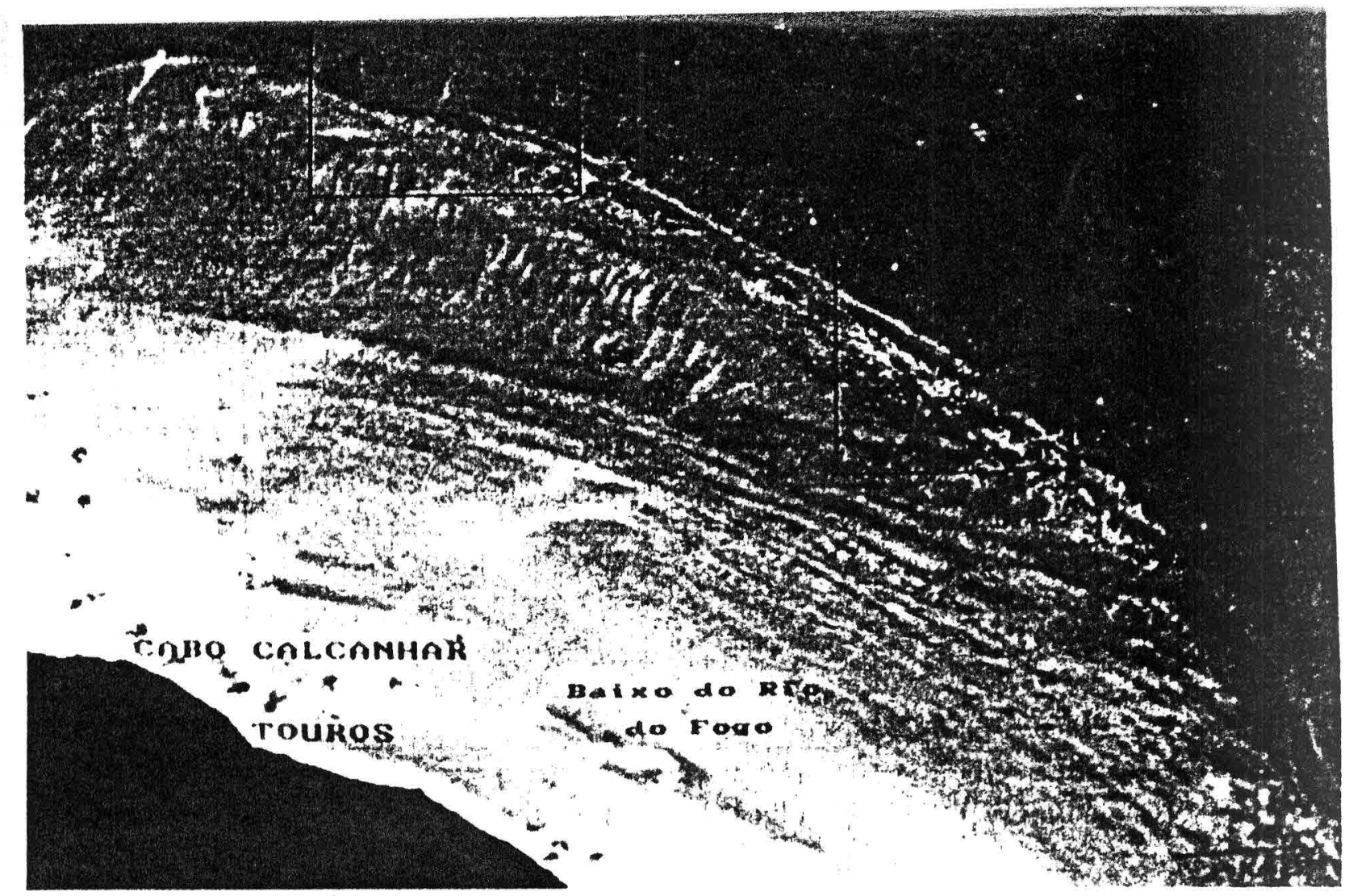

Figure 2. TM-Landsat image of the seafloor of the study area, path/row $214 / 64$, quadrant A, band 1, passage 5 January 1989, with the position of the two zoomings corresponding to figures $4(a)$ and $4(b)$, with indications for the transects $\mathrm{A}, \mathrm{B}$ and $\mathrm{C}$. The inshore features aligned in the longshore direction with the coral reef called Baixo do Rio do Fogo are also coral/algal reefs. Scale bar: $3 \mathrm{~km}$.

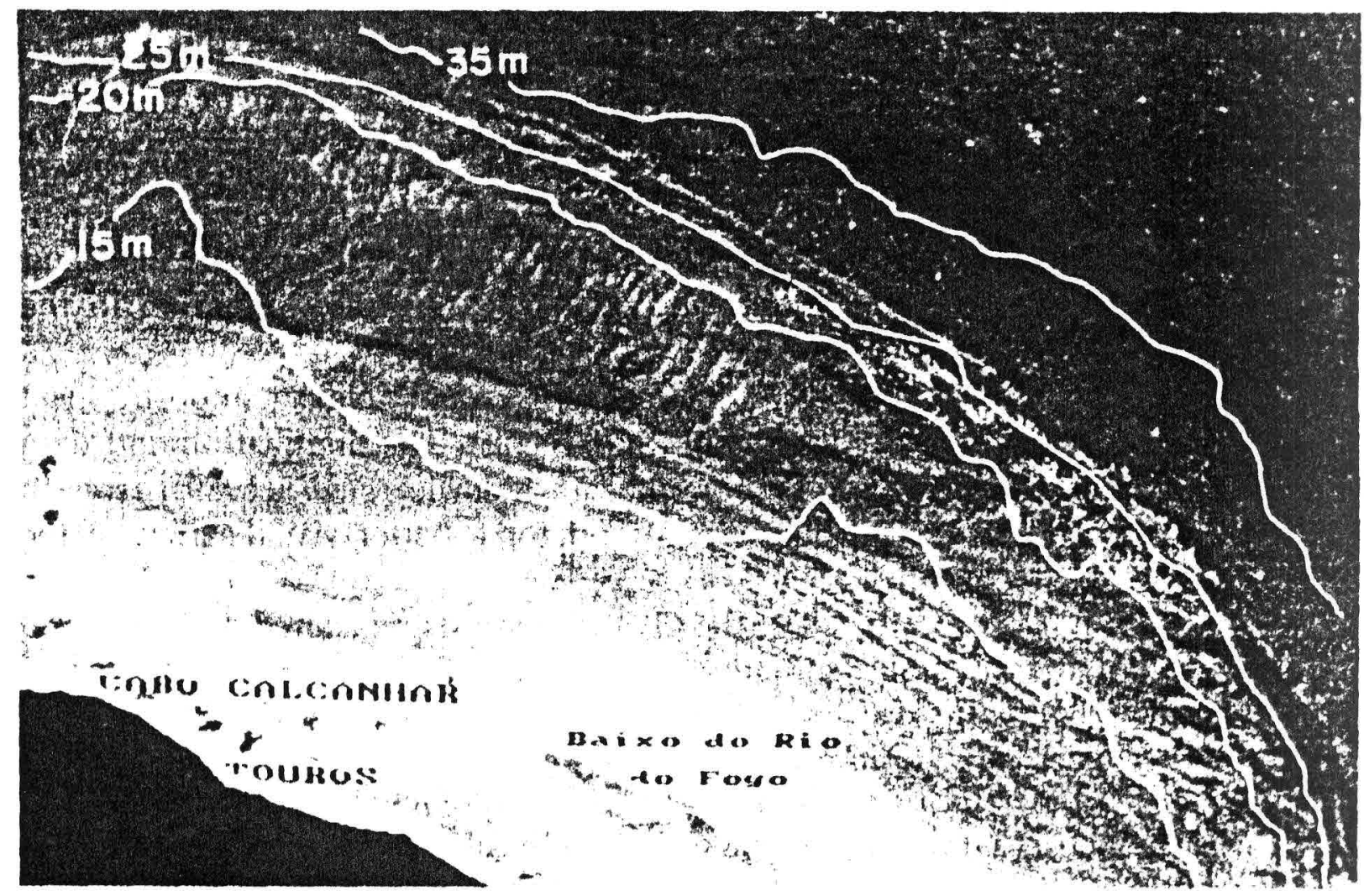

Figure 3. Registration of low-resolution bathymetric data from the Navy smooth sheet $n$. B800-3/71 with the TM image. The isobaths were smoothed by interpolation to filter out spurious longshore 'bumps' in the raw data. The $30 \mathrm{~m}$ isobath was omilted to avoid line crowding in the image. It is just offshore of the 'shorcline'. 
sections, petrographic, and stable isotope analysis were done at two laboratories: the Instituto de Geociências, Universidade da Bahia, and CENPES/PETROBRAS.

\section{Location of submerged outcrops and ancient shoreline characterization}

Figure 3 suggests that at the indicated $25 \mathrm{~m}$ isobath there is a strong discontinuity in bathymetry, due to the contrast in upwelling radiance revealing the conspicuous lineament, separating a bright non-homogeneous area from a darker homogeneous region of different texture. Moreover there is a highly reflecting line, suggesting a long sand strip comprising this lineament. The lineament was further investigated by zooming, to see if any distinct feature resembling the long slender beachrock 'reefs', so characteristic of east Brazilian beaches (Branner 1904, Vianna 1986) could be located. We can use beachrock as indicators for sea-level stillstands and ancient shorelines, in the way suggested by Hopley (1986).

Three possible sites were chosen for in situ analysis. These are indicated as sites $\mathrm{A}, \mathrm{B}$ and $\mathrm{C}$ in figure 2, with the corresponding echosounder transects also recorded. Transects A and B are shown in more detail in figure $4(a)$. Transect $C$ is shown in Figure $4(b)$. These transects were planned to cross over features well-known by the fishermen, which are visible in the images in Figures $4(a)$ and $4(b)$. Transects $A$ and B both cross over the long beachrock outcrop called Risca do Liso by local fishermen from Touros, while transect $\mathbf{C}$ crosses over a well-known shallow called Risca da Gameleira.

Features $\mathrm{A}$ and $\mathrm{C}$ were later identified by the fishermen as corresponding to their fishing sites called Risca do Liso and Risca do Borges, respectively.

Figures $5(a), 5(b)$ and $5(c)$ show the echosounder profiles over sites A, B and C, respectively. Observation of these figures reveal the correctness of an image interpretation of a bathymetry gradient typical of a shoreface, not apparent in the published bathymetric data.

\section{Visual description of the beachrock reefs and the sand strip}

Although considerable literature has been produced on Brazilian beachrock reefs (Oliveira et al. 1990) a clear-cut mascroscopic classification distinguishing the observed morphological differences between them based on composition, diagenetic and erosional processes characterizing their evolution in time, is lacking. Most of these reefs have a network of caves, which probably originated from the erosion caused by tides, waves, and meteoric water percolation at times of sea-level lower than the level of the upper surface. A large number of the present-day long active beachrock coastlines in N-E Brazil seems to correspond to a sea-level stand of about $3 \mathrm{~m}$ higher than today, probably of the same age as the ones studied by Oliveira $e t$ al. (1990).

The beachrock of site A was found to have its plane upper surface partly covered by quartz sand, with several large craters caused by collapse of the roof of caverns of maximum height of $1.5 \mathrm{~m}$. On the other hand, the outcrop on site $C$ is very high, and no sample of it was yet studied. During the northbound navigation from site $C$ to site A, a clear white strip was seen all the way, corresponding to the white strip seen in the imagery.

Several other sites to the south of the city of Natal were inspected by diving, and the description is the same around the $25 \mathrm{~m}$ depth interval. However, their discovery was recent and detailed studies should be made in the near future. 


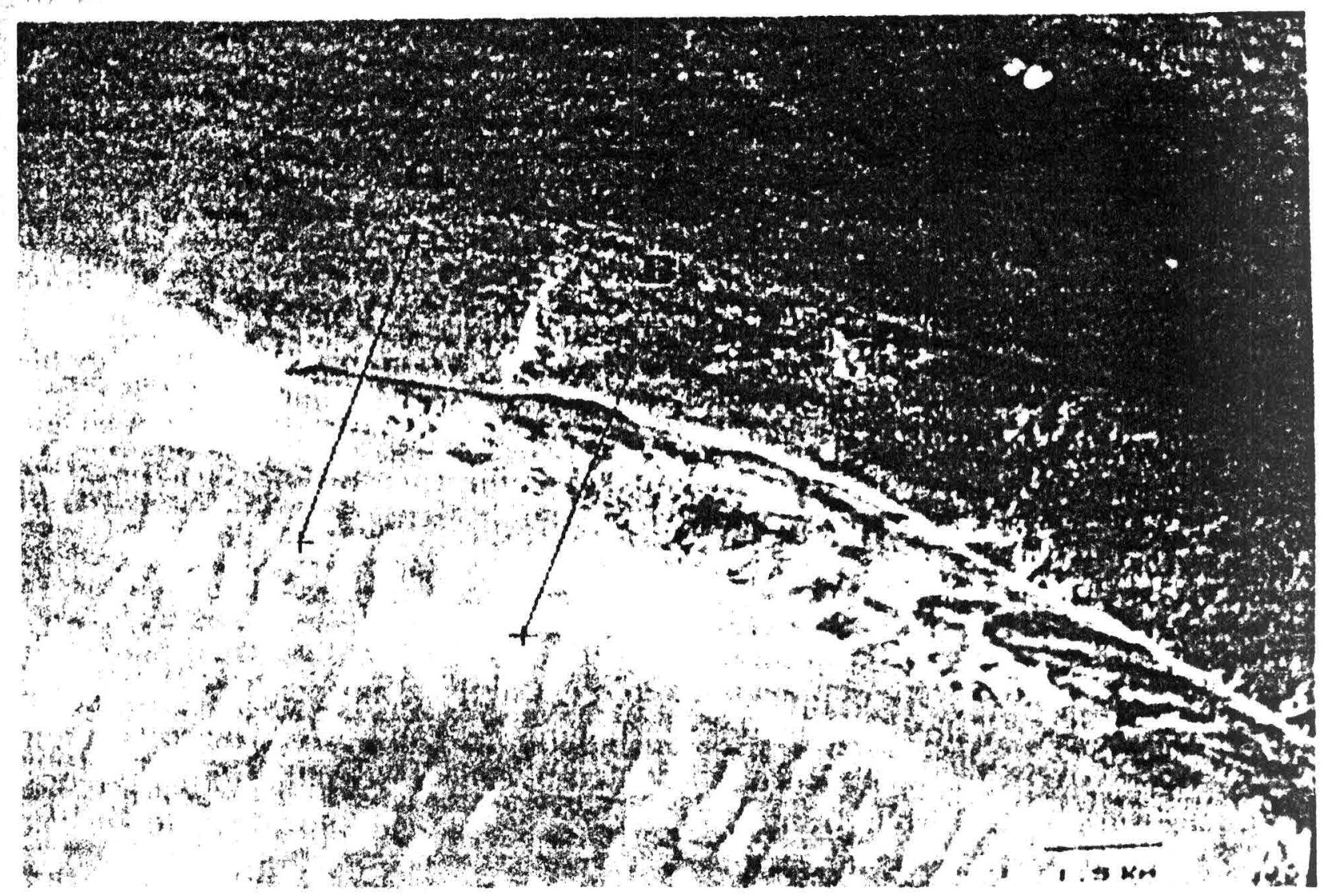

(a)

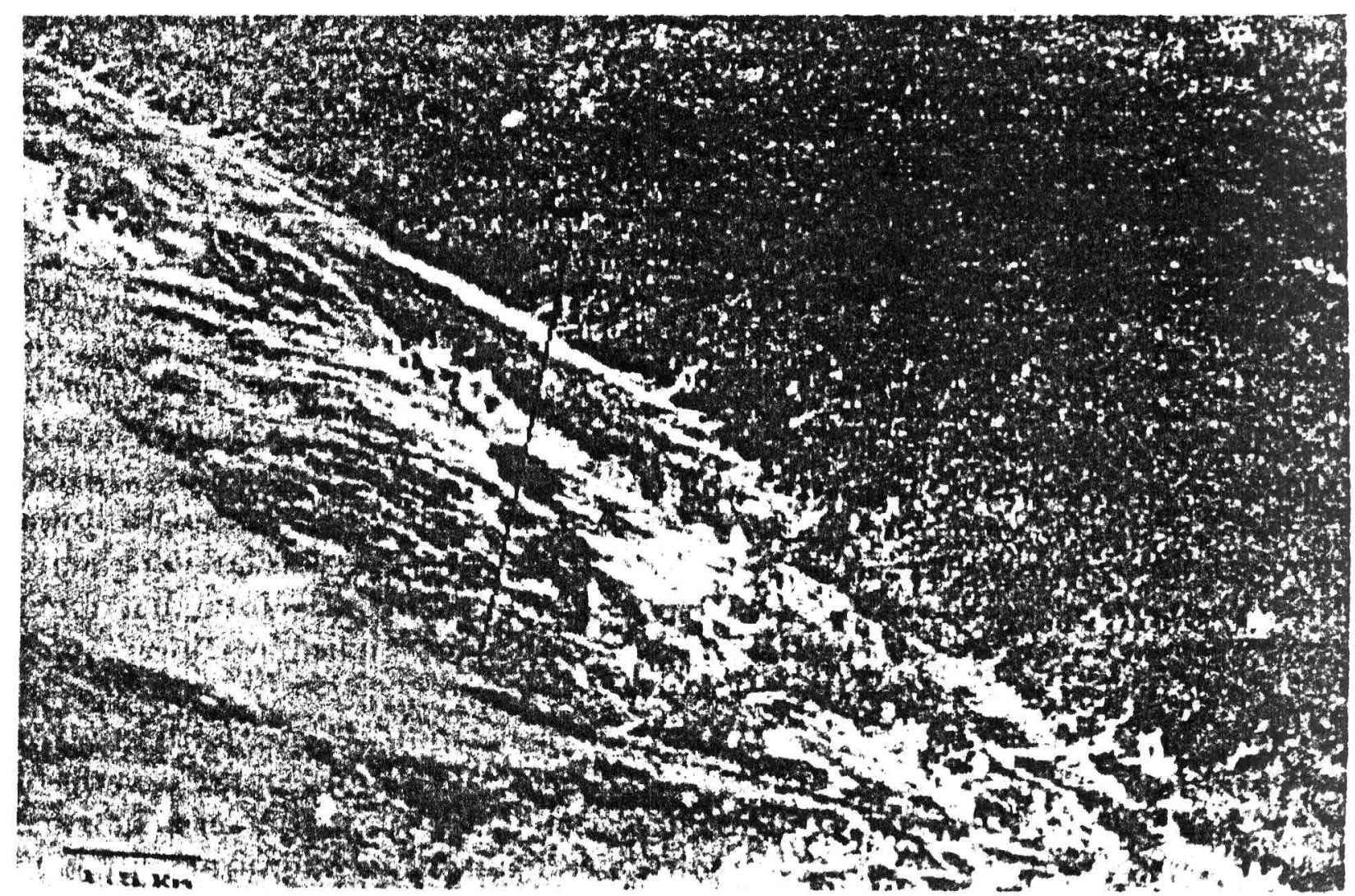

(b)

Figure 4. (a) Location of echosounder transects A and B crossing over the long beachrock outcrop called Risca do Liso; (b) Location of echosounder transect C,. crossing over a well-known shallow fishing spot (very dark spot on the middle of the transect) called Risca da Gameleira. Scale bar: $1.5 \mathrm{~km}$. 
(a)

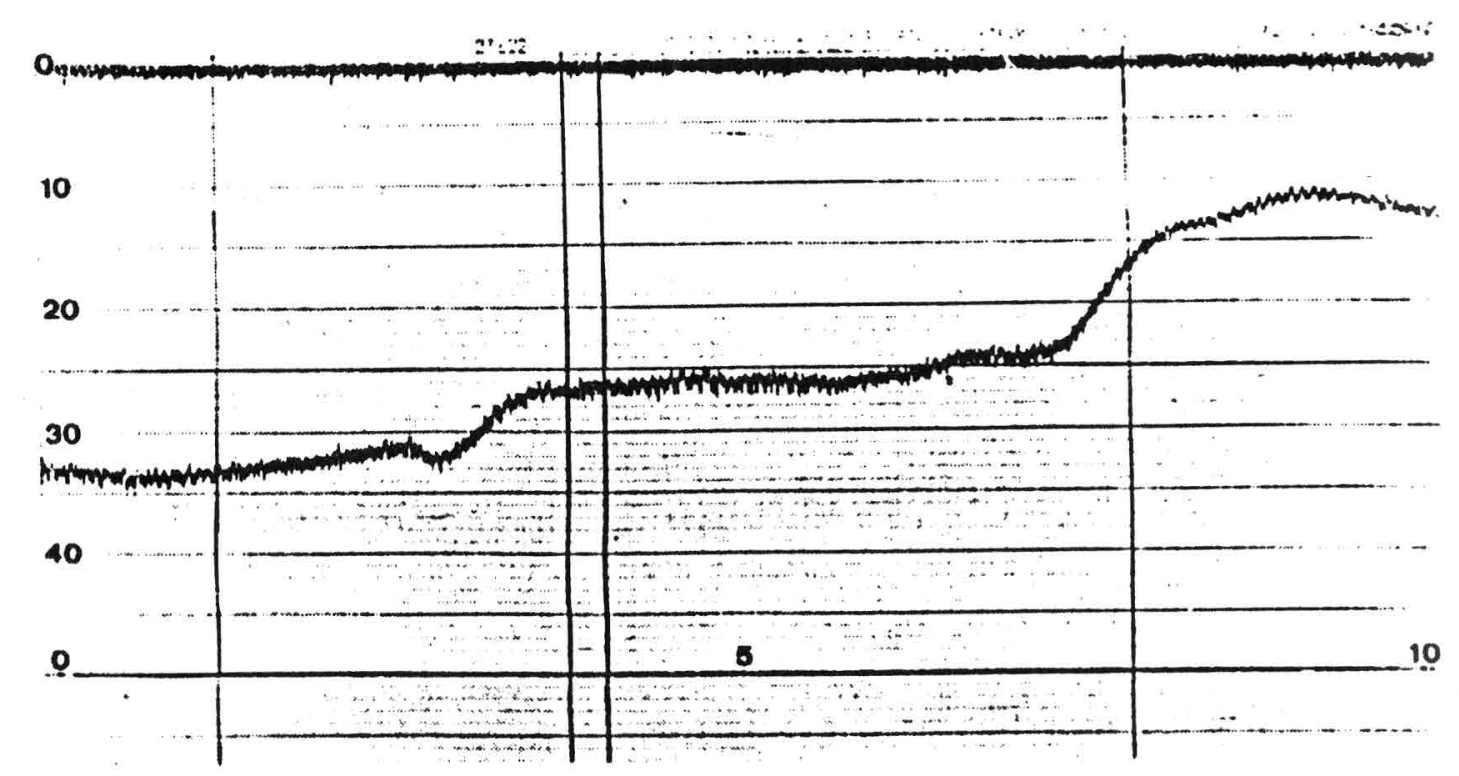

(b)

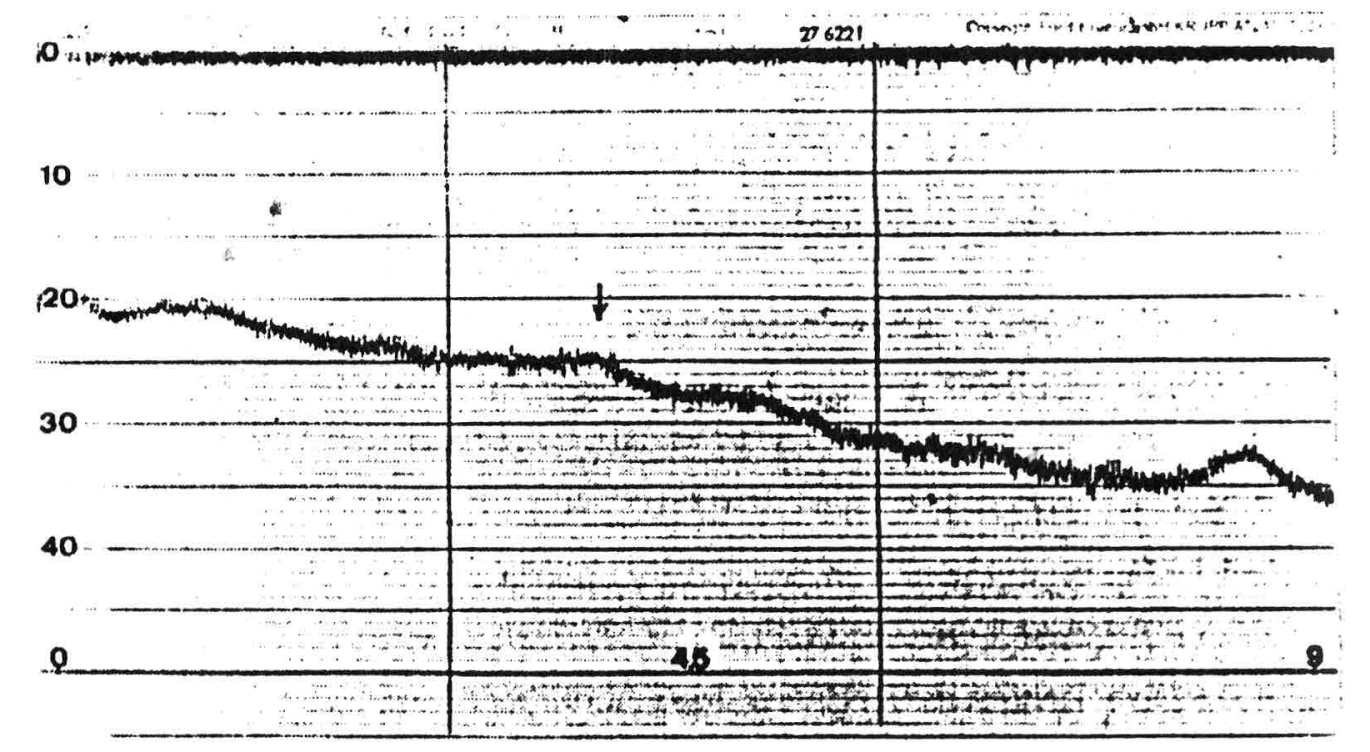

(c)

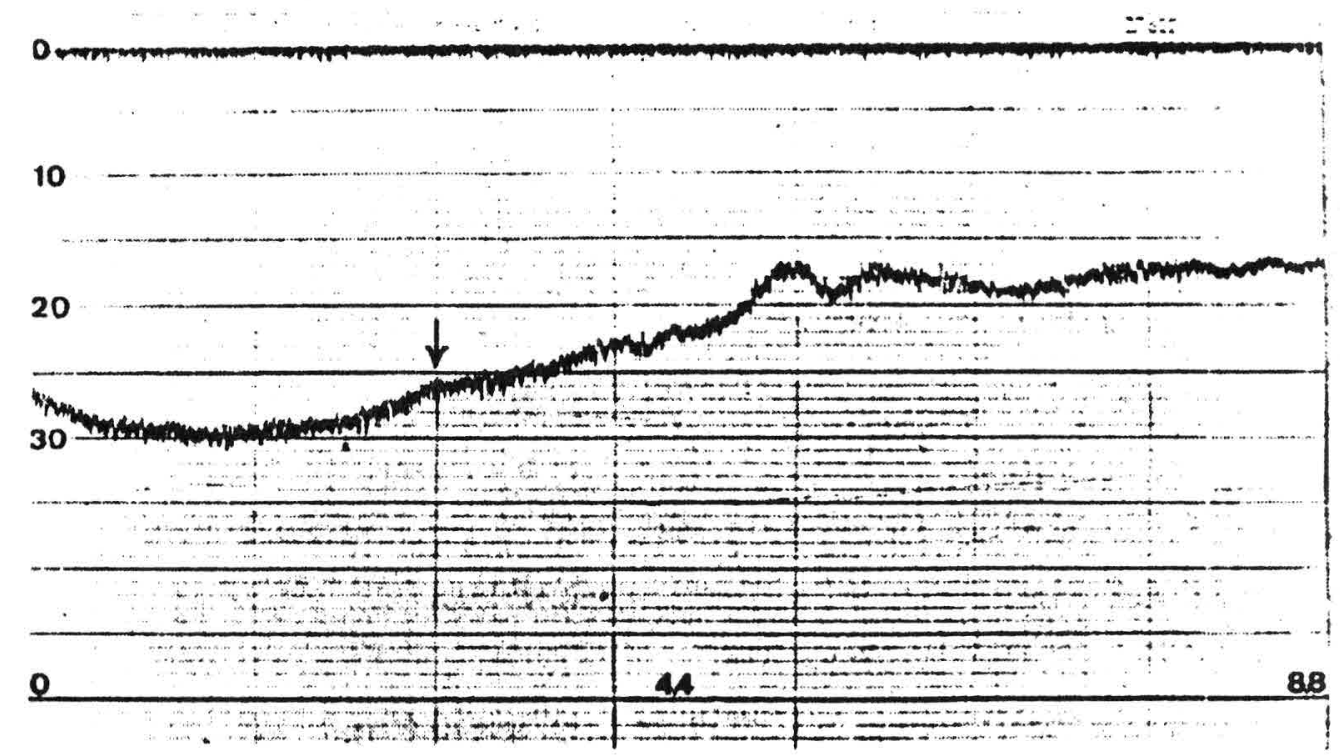

Figure 5. Echosounder transects A, B and C. (a) Transect A taken in the offshore-inshore direction, with the sharp gradient probably corresponding to a shoreface just to the left of the double vertical line. The shallow hill on the right is the sand ridge seen in Figure $4(a)$. (b) Transect B taken in the inshore-offshore direction. Position of the beackrock outcrop indicated by arrow. (c) Transect $\mathrm{C}$ taken in offshore-inshore direction. Horizontal scale in kilometres, vertical scale in metres, calibrated including hydrographic adjustment with tidal data. 
Offshore of all these outcrops, a quartz sand sheet with no ripple marks was always present, sloping gently towards the $25-30 \mathrm{~m}$ depth range, suggesting that it corresponds to a shore face. It should be worth noticing that inshore of the $25 \mathrm{~m}$ depth range, one can only find beachrock outcrops at less than around $8 \mathrm{~m}$ depth.

\section{Laboratory analysis of samples}

Samples taken from the inshore side of the beachrock reef on site A, called Risca do Liso, were obtained on two different occasions. Analysis of the first sample, obtained in 1988, resulted in the following decription (Vianna and Solewicz 1988): quartz sandstone cemented by high $\mathrm{Mg}$-calcite with crystal size around 5-10 $\mu \mathrm{m}$, and a predominance of rounded to subrounded sand sized quartz grains. Pebbles up to $1 \mathrm{~cm}$ were found, but bioclastic material was absent.

The second sample was obtained in 1989. It is characterized by a medium to poorly sorted quartz, bioclastic grainstone with subrounded to rounded grains. These are similar to the surrounding uncemented sands. Two cement generations were seen: firstly, an ubiquitous isopachous fringe of fibrous, possibly high $\mathrm{Mg}$ calcite, with a maximum width of $90 \mu \mathrm{m}$, showing distinct polygonal interface boundaries. The second cement comprises fans of rhombo-hedral crystals of $20 \mu \mathrm{m}$ presumed to be of high "Mg-calcite, occupying small portions of the interparticle pores.

The diagenetic fabric may be associated to beachrock, formed in the marine phreatic (active) zone (Longman 1980). Although no typical vadose cementation was seen in our sample, present day active beachrocks in Egypt failed to show any vadose cement (Holail and Rashed 1992), which is usually considered as diagnostic of beachrock cementation.

Whole rock stable isotope analysis showed that the relative concentration values for ${ }^{13} \mathrm{C}(3 \cdot 15 \%)$ and ${ }^{18} \mathrm{O}(0 \cdot 79 \%)$ are inside the limits usually observed in carbonate cements precipitated in the intertidal zone (Hopley 1986).

Similarities between active emerged beachrocks in the same area (Oliveira et al. 1990), and the submerged reef complex with respect to their external morphology, stand out clearly. The presence of erosion caverns on the lower part, on both complexes, illustrate that they might have been subjected to waves and tides, for a comparable time span.

\section{Discussions on paleoclimatic data}

Geomorphological evidence was presented which identified a lineament found in TM-Landsat image of the seafloor as an ancient shoreline. The data base, although preliminary, support this argument in a sufficiently compelling way.

The structural setting to which this area belongs has been described by Asmus (1984), and more recently by Bertani et al. (1990). The area is located over a structural high (Touros high), and belongs to an eastern extension of the Potiguar Basin although belonging to the Pernambuco-Paraiba System (Mabessone and Alheiros 1988).

The available tide-gauge data that can be used to estimate possible motions of tectonic origin are the data from Recife and Fortaleza (Aubrey et al. 1988), with records obtainable from the Permanent Service of Mean Sea-Level (PSMSL). The data from Recife seem to be more representative, since between this city and our study area there are no rift systems, as is the case of Fortaleza, which is located to the west of a fault system (triple junction) and exactly over the boundary of two 
distinct sedimentary basins. In fact, tide-gauge data indicates that Fortaleza is subsiding at an estimated rate of $3.5 \mathrm{~mm} \mathrm{yr}^{-1}$, whereas Recife presents an estimated uplift rate of $0.2 \mathrm{~mm} \mathrm{yr}^{-1}$ (Aubrey et al. 1988). We can extrapolate such an uplift rate to obtain the depth correction for the last $10 \mathrm{kyrs}$, which would place the relative depth at $27 \mathrm{~m}$ below the present sea-level datum.

In order to get an age estimate of this shoreline prior to local dating studies, a carefully calculated eustatic curve available for the closest possible area in the western Atlantic was analysed: the Barbados curves of Fairbanks (1989), including the U-Th calibration curve (Bard et al. 1990, Fairbanks, private communication), which place the $27 \mathrm{~m}$ depth around 9500 B.P. (figure 6).

However, no signature of a sea-level stand at this epoch can be seen in the Fairbanks interpolated eustatic curve, unless his raw data points are reinterpreted. In fact his non-interpolated data seem to indicate a major stabilization (and even a slight regression) starting around $9700 \mathrm{yr}$ B.P. down to about $8800 \mathrm{yr}$ B.P. As a further example, the major outlier point at $30 \mathrm{~m}$ depth, if reinterpreted as representing a regression, could indicate a very abrupt decrease in sea-level around $8500 \mathrm{yr}$ B.P. of around $500 \mathrm{yr}$ duration, in the range of $20-28 \mathrm{~m}$ depth. For our purpose, the outlier at around $8800{ }^{14} \mathrm{C}$ B.P. and $24 \mathrm{~m}$ depth could be reinterpreted as a sharp maximum, followed by a minimum at $8100{ }^{14} \mathrm{C}$ B.P., at $28 \mathrm{~m}$. These facts can be shown to be consistent with other results reported in Fairbanks (1989), i.e., if a long

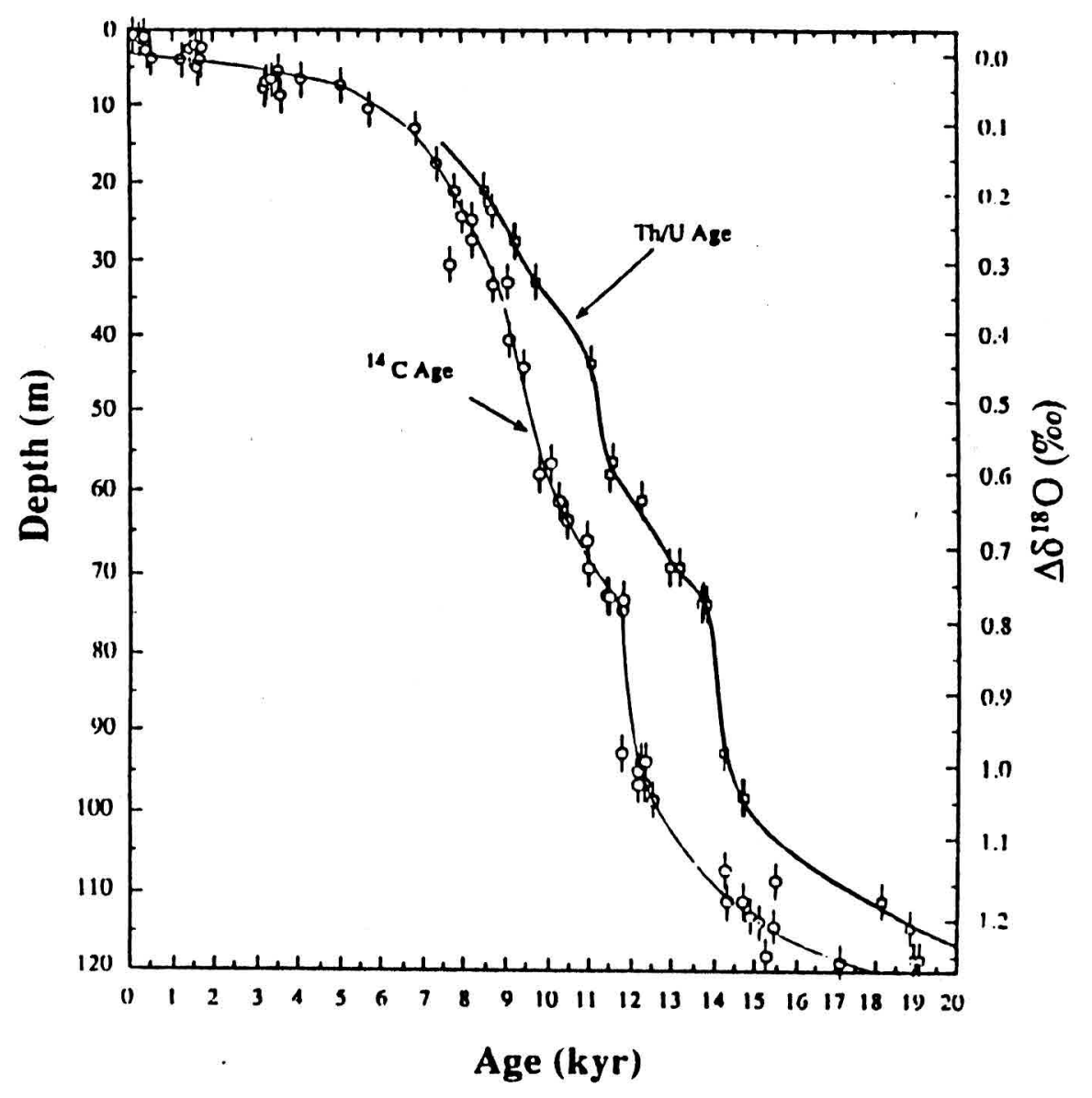

Figure 6. Eustatic curves calculated by Fairbanks (private communication) from Barbados corals, exhibiting both the ${ }^{14} \mathrm{C}$ and $\mathrm{Th} / \mathrm{U}$ Ages. The high resolution dating $( \pm 200 \mathrm{yr})$ suggests that a non-interpolated curve in the $20-40 \mathrm{~m}$ depth interval could be significant. 


\section{L. Vianna et al.}

global sea-level stand in the Younger Dryas chronozone is allowed for. He presents evidences that two huge meltwater pulses pouring freshwater into the north Atlantic might have been responsible for sea-level growth between 14-9 kyr B.P., with the Younger Dryas corresponding to a minimum in the fluxes of meltwater into the North Atlantic.

The calculated discharge had maximum rates of $14000 \mathrm{~km}^{3} \mathrm{yr}^{-1}(13 \mathrm{kyr}$ B.P.) and $9500 \mathrm{~km}^{3} \mathrm{yr}^{-1}$ (10 kyr B.P.), with a minimum of $2700 \mathrm{~km}^{3} \mathrm{yr}^{-1}$ (11 kyr B.P.). We can, therefore, make a rough estimate of the corresponding sea-level rise rates. The simple volume rate equation below can be applied:

$$
d V / d t=A d Z / d t
$$

where $A$ is the total global ocean area of a fixed average depth ocean, $V$ is the ocean water volume and $Z$ is the average depth. We get the estimates of $47 \mathrm{~mm} \mathrm{yr}^{-1}$, $32 \mathrm{~mm} \mathrm{yr}^{-1}$ and $9 \mathrm{~mm} \mathrm{yr}^{-1}$, respectively, if we use for $A$ an estimate of 75 per cent of the Earth's surface area. However, by estimating these quantities using the slope of the Fairbanks eustatic curve, one gets less than $10 \mathrm{~mm} \mathrm{yr}^{-1}$ maximum rates. This means that a high resolution study of sea-level growth rate would be very important to resolve this issue. Moreover, we have reasons to suspect that not only two meltwater pulses, but at least a third one around 9000 B.P. would be required to accommodate all the data from other ancient shorelines found between $50 \mathrm{~m}$ and $15 \mathrm{~m}$ depths.

The paleoclimatic data of the northern hemisphere during the deglaciation (Overpeck et al. 1989) was reviewed to see if we could find signals that could correlate to our ancient shoreline. We found that only the Younger Dryas cold event could be interpreted as possibly a cause for a major stabilization of global sea-levels in that time zone. However, at around $9000 \mathrm{yr}$ B.P. (corrected dating), the inferred temperature record for the South Island, New Zealand, indicates a high amplitude cold spell of less duration, but about the same amplitude, as the earlier one of long duration corresponding in timing to the Younger Dryas (Burrows 1989).

The most recent data base that throws some light on this subject is contained in the higher resolution faunal records obtained from a sediment core from the Norwegian Trench (Lehman and Keigwin 1992). It is shown there, that the Younger Dryas corresponded to two cold spells. The authors also suggest that the Younger Dryas was followed by another minor reduction in inflow of Atlantic water into the Norwegian sea, possibily related to another cold spell of small duration. They point out that the stable interglacial circulation regime was only established after $8.8 \mathrm{kyr}$ B.P. All this consistent with our picture suggested above.

In relation to evidence of stillstands from the Pacific, Ota et al. (1988) presented an eustatic curve for eastern North Island, New Zealand, exhibiting a long-period (1000 yr) stabilization corresponding to $25 \mathrm{~m}$ depth.

These results, together, strongly suggest that a long-lived stabilization, which was responsible for the shaping of the shoreline here reported, could very well be related to the global event corresponding to the Younger Dryas. The related question of the competition between abrupt sea-level growth and Bruun's coastal retreat (Swift et al. 1972) seems to be also central to the understanding of the frequent occurrence of the terraced morphology limited by drowned shorelines, found on several trailing edge continental shelves, which in the case of north-east Brazil can be sometimes mapped by TM-Landsat data. Numerical modelling of time-dependent Bruun's coastal retreat could shed some light in this paleoclimatology issue. 
This article described an application of $1 \mathrm{M}$-Lanasat imagery in a stuuy iciaicu to an aspect of the Holocene evolution of the shelf surface of north-east Brazil. By describing a drowned shoreline, and trying to relate its large-scale morphology with global paleoclimatic data, we raised a provocative problem in abrupt global climate change dynamics, in the sub-century time scale.

We conjectured before (Vianna and Solewicz 1988, Vianna et al. 1991) that the lineament here discussed was around $22 \mathrm{~m}$ depth, based on a hand-held gauge. However, with precise echosounder data and corrections for tidal range, we determined that the best estimate is $25 \mathrm{~m}$ depth. It was shown to be suggestive of a drowned shoreline, possibly corresponding to a return to glacial conditions between $11000-9000 \mathrm{yr}$ B.P., the Younger Dryas cold event being the best candidate. We exposed a spectrum of simple problems which should be solved in order to incorporate into paleoclimatology the compelling fact that drowned shorelines have been detected worldwide, which implies that sea-level stands really occured in the past. These stands, and the sudden acceleration of sea-level rise, must be correlated to abrupt changes in the meltwater discharge from glaciers and ice sheets erosion from both Arctic and Antarctic regions.

These findings should be followed by a general sedimentological survey of the quaternary deposits of the area, with a strong dating component, in parallel to the development of an ocean circulation model that takes into account the effect of brief meltwater pulses and their effect on global sea-levels, and a dynamical model of the evolution of the shelf surface.

\section{Acknowledgments}

We thank Dr R. Fairbanks of Columbia University for supplying us with fig. 6 . We thank the Divisão de Geração de Imagens (DGI-INPE/Cachoeira Paulista) for the pre-processing of the TM image. We also thank Zelinda Leão (Instituto de Geociências, Universidade Federal da Bahia), and Joel Castro and Paulo Tibana (CENPES/PETROBRAS) for support with the petrographic work; to the Comando Naval do Nordeste and $3^{\circ}$ Districto Naval for support on the echosounder transects, and Jose Bezerra Neto for support with the diving operations. We also thank Ed Sarachik from the University of Washington for calling attention for the recent work of Lehman and Keigwin. Alexandre P. Cabral and Douglas F. M. Gherardi were supported by CNPq, Fellowships No. 830218/89 and No. 461036-90-8 (RHAE), respectively, during this work.

\section{References}

Aubrey, D. G., Emery, K. O., and UchupI, E., 1988, Changing coastal levels of the South America and the caribbean region from tide-gauge records. Tectonophysics, 154, 269-284.

Asmus, H. E., 1984, Geologia da Margem Continental Brasileira. In Geologia do Brasil, edited C. Schobbenhaus, D. A. Campos, G. D. Derze, H. E. Asmus (Brasilia: DNPM), pp. 443-472.

Bard, E., Hamelin, B., Fairbanks, R. G., and Zindler, A., 1990, Calibration of the ${ }^{14} \mathrm{C}$ timescale over the past 30000 years using mass spectrometer U-Th ages from Barbados corals. Nature, 345, 405-410.

Bertani, R. T., Costa, I. G., and Matos, R. M. D., 1990, Evolução tectono-sedimentar, estilo estrutural e habitat do petróleo na Bacia Potiguar. In Origem e evolufaão de bacias sedimentares, edited G. P. De Raja Gabaglia, E. J. Milani (Rio de Janeiro: Petrobrás), pp. 291-309. 
Branner, J. C., 1904, The stone reefs of Brazil. Their geological and geographical relations, with a chapter on the coral reefs. Bulletin of the Museum of Comparative Zoology, 44, 207-275.

Burrows, C. J., 1989, A chronology for cool-climate episodes in the Southern Hemisphere 12000-1000 yr B.P. Paleogeography, Paleoclimatology, Paleoecology, 27, 287-347.

Cabral, A. P., Mantovani, J. E., Costa. M. P. F.. and Lima, R. A. F., 1990, Redução do 'striping' de imagens TM-LANDSAT de ambientes aquáticos através de técnicas de filtragem espacial. In Simpósio Brasileiro de Sensoriamento Remoto, 6., Manaus, Brazil, 24-29 June, Proceedings, 4, pp. 833-839.

FAIRBANKS, R. G., 1989, A 17000 -year glacio-eustatic sea level record: influence of glacial melting rates on the Younger Dryas event and deep-ocean circulation. Nature, 342 , 637-642.

França, A. M. C., Coutinho, P. N., and Summerhayes, C. P., 1976, Sedimentos superficiais da margem continential nordeste brasileira. Revista Brasileira de Geociências, 6, 71-88.

Gabriel, A. K., Goldstein, R. M., and Zebker, H. A., 1989, Mapping small elevation changes over large areas: differential RADAR interferometry. Journal of Geophysical Research, 94, 9183-9191.

Hick, P., and Scoones, R., 1990, Satellite-derived imagery for water penetration and its relevance to fisheries in the Kimberley region of Western Australia. CSIROExploration Geoscience Restricted Report, (Canberra, Australia: CSIRO), 47 p.

HolaIL, H., and RASHED, M., 1992, Stable isotopic composition of carbonate-cemented recent beachrock along the Mediterranean and the Red Sea coasts of Egypt. Marine Geology, 106, 141-148.

HOPLEY, D., 1986, Beachrock as a sea-level indicator. In Sea-level research: a manual for the collection and evaluation of data, edited by O. van de Plassche (Norwich: Geo Books), pp. 157-174.

Imbrie, J., and Imbrie, K. P., 1979, Ice Ages. (Cambridge: Harvard University Press).

JUPP, D. L. B., 1988, Background and extensions to Depth of Penetration (DOP) mapping in shallow coastal waters. In Symposium on Remote Sensing of the Coastal Zone, 5, (Queensland, Australia: CSIRO), pp. 77-94.

Lehman, S. J., and KeIGWIN, L. D., 1992, Sudden changes in North Atlantic circulation during the last deglaciation. Nature, 356, 757-762.

Longman, M. W., 1980, Carbonate diagenetic textures from nearsurface diagenetic environments. American Association of Petroleum Geologists Bulletin, 64, 461-487.

Lyzenga, D. R., 1978, Passive Remote Sensing techniques for mapping water-depth and bottom features. Applied Optics, 17, 379-383.

LyZENGA, D. R., 1979, Shallow-water reflectance modelling with application to Remote Sensing of the ocean floor. In International Symposium on Remote Sensing of Environment 13. Ann Arbor, USA, 23-27 April 1979. Proceedings, 1, pp. 583-602.

Mabessone, J. M., and Alheiros, M. M., 1988, Origem da Bacia Sedimentar Costeira Pernambuco-Paraiba. Revista Brasileira de Geociências, 18, 476-482.

Oliveira, M. I. M., Bagnoli, E., Farias, C. C., Nogueira, A. M. B., and Snatiago, M., 1990, Considerações sobre a geometria, petrografia, sedimentologia, diagênese e idade dos beachrocks do Rio Grande do Norte. In Congresso Brasileiro de Geologia 36. Proceedings, 2, (Natal, Brazil: Sociedade Brasileira de Geologia), pp. 621-634.

Ota, Y., Berryman, K. R., Hull, A. G., Miyauchi, T., and Iso, N., 1988, Age and height distribution of Holocene transgressive deposits in eastern North Island, New Zealand. Paleogeography', Paleoclimatic, Paleoecology, 68, 135-151.

Overpeck, J. T., Peterson, L. C., KiPP, N., ImPrie, J., and Rind, D., 1989, Climate change in the circum-North Atlantic region during the last deglaciation. Nature, 338, 553-557.

PolCyn, F. C., and Lyzenga, D. R., 1975, Remote bathymetric and shoal detection with ERTS. In NASA-CR-ERIM-193300-51-F (Ann Arbor: NASA), p. 55.

Solewicz, R., CABral, A. P., and ViannA, M. L., 1989, Associação do sistema de informações geográficas com imagens TM-Landsat para classificação de unidades geoecológicas da plataforma continental nordeste do Brasil. In Simpósio Latino Americano de Sensoriamento Remoto, 4. Bariloche, November 1989. Proceedings, 3, (São José dos Campos, Brazil: INPE), pp. 1188-1197. 
Swift, D. J. P., Kofofd, J. W., Saulsiury, F. P., and Sears, P., 1972. Holocenc cvolution of the surface, central and southern Atlantic shelf of North America. In Shelf sediment transport: process and pattern, cdited by D. B. Duanc and O. H. Pilkey (Stroudsburg: Dowden, Hutchinson and Ross), pp. 499-574.

Tooley, M. J., and Shennan, I., 1987, Sea-level changes. (New York: Basil Blackwell).

VAN ANDEL, T. H., and Lianos, N., 1984, High resolution seismic reflection profiles for the reconstruction of postglacial transgressive shorelines: an example from Greece. Quarternary Research, 31, 31-45.

Van de Plassche, O., 1986, Sea-level research: a manual for the collection and evaluation of data (Norwich: Geo Books).

VAN Hengel, W., and Spitzer, D., 1991, Multi-temporal water depth mapping by means of Landsat TM. International Journal of Remote Sensing, 12, 703-712.

VianNa, M. L.. 1986. On the ecology and intraspecific variation in the spiny lobster Panulirus echinatus Smith 1869, (Decapoda, Palinuridae) from Brazil. Crustaceana, 51, 25-37.

VianNa, M. L., and SolEwiCZ, R., 1988, Feições fisiográficas submarinas visiveis por imagens de satélite. In Simpósio Brasileiro de Sensoriamento Remoto, 5. Natal, Brazil, II-15 October, 1988. Proceedings, 3, (São José dos Campos. Brazil: INPE), pp. 581-587.

Vianna, M. L.. Solewicz, R., and Cabral, A. P., 1989, Early Holocene sea-level stillstands in the Brazilian northeast mapped by satcllite. In International Symposium on Glohal Changes in South America during the Quaternary: Past-Present-Future, São Paulo, Brazil, 8-12 May 1989. Proceedings, (São Paulo, Brazil: VSP), pp. 250-254.

Vianna, M. L., Solewicz, R., Cabral, A. P., and Testa, V., 1991, Sandstream on the Northeast Brazilian Shelf. Continental Shelf Research, 11, 509-524.

Vianna M. L., and Cabral, A. P., 1992, Landsat Thematic Mapper and Spot imagery of submerged sedimentary features in the 10-45 m depth range: a case study in the NE Brazilian Shelf (in preparation, to be submitted to Geocarto International). 